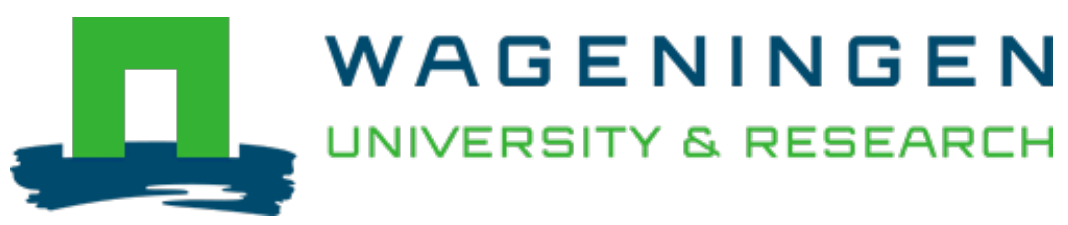

\title{
Edaphic characteristics drive functional traits distribution in Amazonian floodplain forests
}

\author{
Plant Ecology \\ Mori, Gisele Biem; Poorter, Lourens; Schietti, Juliana; Piedade, Maria Teresa Fernandez \\ https://doi.org/10.1007/s11258-020-01110-4
}

This publication is made publicly available in the institutional repository of Wageningen University and Research, under the terms of article $25 \mathrm{fa}$ of the Dutch Copyright Act, also known as the Amendment Taverne. This has been done with explicit consent by the author.

Article 25 fa states that the author of a short scientific work funded either wholly or partially by Dutch public funds is entitled to make that work publicly available for no consideration following a reasonable period of time after the work was first published, provided that clear reference is made to the source of the first publication of the work.

This publication is distributed under The Association of Universities in the Netherlands (VSNU) 'Article $25 \mathrm{fa}$ implementation' project. In this project research outputs of researchers employed by Dutch Universities that comply with the legal requirements of Article $25 \mathrm{fa}$ of the Dutch Copyright Act are distributed online and free of cost or other barriers in institutional repositories. Research outputs are distributed six months after their first online publication in the original published version and with proper attribution to the source of the original publication.

You are permitted to download and use the publication for personal purposes. All rights remain with the author(s) and / or copyright owner(s) of this work. Any use of the publication or parts of it other than authorised under article $25 \mathrm{fa}$ of the Dutch Copyright act is prohibited. Wageningen University \& Research and the author(s) of this publication shall not be held responsible or liable for any damages resulting from your (re)use of this publication.

For questions regarding the public availability of this publication please contact openscience.library@wur.nl 


\title{
Edaphic characteristics drive functional traits distribution in Amazonian floodplain forests
}

\author{
Gisele Biem Mori $(\mathbb{D} \cdot$ Lourens Poorter $(\mathbb{D} \cdot$ Juliana Schietti $(\mathbb{D} \cdot$ Maria Teresa Fernandez Piedade
}

Received: 14 January 2020/Accepted: 18 December 2020

(C) The Author(s), under exclusive licence to Springer Nature B.V. part of Springer Nature 2021

\begin{abstract}
Understanding how environmental factors drive community assembly remains a major challenge in community ecology, especially in biodiverse tropical forests. We investigated how environmental filters affect functional trait distribution in two contrasting types of floodplain forest in the Brazilian Amazon: white-water forest (várzea) and black-water forest (igapo). We placed 40 plots of $625 \mathrm{~m}^{2}$ along a flooding gradient in Central Amazonia and measured for edaphic variables and 11 functional traits related to use of resources and flooding tolerance/avoidance. We assessed functional distribution by calculating
\end{abstract}

Communicated by Christopher Anderson.

Supplementary Information The online version contains supplementary material available at https://doi.org/10.1007/ s11258-020-01110-4.

G. B. Mori $(\bowtie)$ · J. Schietti · M. T. F. Piedade Instituto Nacional de Pesquisas da Amazônia, INPA, Avenida André Araújo, 2.936, Petrópolis, Manaus, Amazonas 69.067-375, Brazil

e-mail: giselebiem@gmail.com

G. B. Mori · L. Poorter

Forest Ecology and Forest Management Group, Wageningen University \& Research, WUR. P.O. Box 47, 6700 AA Wageningen, The Netherlands

J. Schietti

Departamento de Biologia, Universidade Federal do Amazonas (UFAM), Av. General Rodrigo Octavio Jordão Ramos, 1200, Manaus, AM 69067-005, Brazil community-trait mean values and trait kurtosis. Analysis of community mean trait values showed that nutrient-rich white-water forests favored trees with productive leaves and fast growth, whereas nutrientpoor black-water forests favored trees with nutrient conservation traits and slow growth. Functional diversity was not related to environmental gradients. Edaphic characteristics act, therefore, as a strong environmental filter leading to trait convergence in these floodplain tree communities.

Keywords Tropical forests - Central amazonia . Floodplains · Environmental gradients $\cdot$ Functional ecology $\cdot$ Tree communities

\section{Introduction}

A major challenge in community ecology is to understand how environmental factors drive community assembly (Grime 2006; Violle et al. 2011). This is especially the case for forests where community assembly is slow because of the gradual growth and long lifespans of trees, and for the tropics, where a high species diversity makes comparisons difficult (Swenson 2013). By focusing on traits rather than species identity, quantitative comparisons between communities that share few or no species are possible, and it also allows to make more generalized 
predictions (McGill et al. 2006; Westoby and Wright 2006). Community assembly may be the result of environmental filters that select species from a regional species pool into the local community based on their trait values (Keddy 1992). The environmental filtering hypothesis predicts that abiotic conditions select for species with similar trait values, which leads to a narrower range in trait values (trait convergence), especially under harsh conditions (Grime 2006). The limiting similarity hypothesis predicts that competition selects for species with different trait values, which leads to increased local functional diversity (Macarthur and Levins 1967), especially under productive, competitive conditions. Here, we assess the relative importance of these two mechanisms of community assembly, by evaluating how gradients in soil fertility and flooding stress affect trait means and variation in Amazonian floodplain forests.

Both environmental filtering and limited similarity have been widely observed in plant communities, and they can operate simultaneously (Cornwell and Ackerly 2009; Swenson and Enquist 2009). For example, an increase in soil fertility not only causes a shift in average trait values of the community, but also increases trait variation (Bernard-Verdier et al. 2012). The observed patterns (i.e., shifts in trait values, convergence, divergence) depend on the trait under consideration because different traits play a different functional role in community assembly. For example, regenerative traits such as leaf dry matter content can show reduced variation with an increase in soil fertility because it is related to competitive strategies of nutrient acquisition by plants whereas reproductive traits such as seed mass can show an increased variation with soil fertility because of spatial and temporal niche partitioning (Bernard-Verdier et al. 2012). Another complicating factor is that different trait combinations (i.e., alternative designs) can result in the same function or fitness in a specific habitat, leading to a higher functional diversity of the community (Dias et al. 2020). The role and importance of environmental filters in community assembly and trait means and variation are, therefore, still not clear and debated.

This study focuses on Amazonian floodplain forest because it represents a unique, diverse, and globally important biome, covering as much as $600,000 \mathrm{~km}^{2}$ (Melack and Hess 2010) and because it is threatened by droughts, fires, and hydroelectric dams (Assahira et al. 2017; Flores et al. 2017; Resende et al. 2019). Floodplain forests also provide an ideal system to address questions on how productivity, stress, and disturbance shape community assembly, due to variation in forest type, tree height, and flood duration. Two main floodplain forest types are found in the Amazon (white- and black-water forests) because of differences in geomorphological formation and the hydro-chemical properties of the rivers (Sioli 1984). Forests occurring along white-water rivers (várzea) with nutrient-rich sediments originate from the Andes or pre-Andean regions (Sioli 1984; Junk et al. 2011). Forests associated with black-water rivers (igapó) are nutrient-poor and originate from the ancient Guyana and Central Brazilian Shields (Sioli 1984; Junk et al. 2011). Because of these differences in nutrient supply, white-water forests are considered highly fertile and productive compared to black-water forests (Karin Furch 1997). Strong differences in fertility and productivity between white- and black-water forests have led to different species strategies in terms of resource acquisition and growth. White-water species capture more nutrients that enable fast-growth producing soft tissues as larger leaves and lighter woods, whereas black-water species conserve more nutrients that enable a slow growth but strong tissues as harder woods and thick leaves (Mori et al. 2019), although the influence of edaphic characteristics on community functional traits is still underexplored.

The flood pulse is another important environmental filter influencing floodplain forest tree communities (Junk et al. 1989). The flood pulse is the result of the high seasonality in precipitation in the Amazon basin combined with low and flat terrains, leading to seasonal flooding of the adjacent vegetation, which may reach up to $10 \mathrm{~m}$ and 290 days per year in the Central Amazon (Wittmann et al. 2010b). Trees show many morphological and physiological trait adaptations to flooding (Lobo and Joly 1998; de Simone et al. 2002; Parolin et al. 2004; Mori et al. 2019). As a result, variation in topography not only causes variation in the depth and duration of flooding, but also leads to differences in species composition, diversity, forest structure, and functioning (Wittmann et al. 2006; Junk et al. 2015).

In this study, we investigated how gradients in soil fertility and flooding intensity affect the functional characteristics (i.e., trait means and trait variation) of Amazonian floodplain forests tree communities. We 
did so by establishing 40 tree plots along these environmental gradients and by measuring for each edaphic variables at each plot. For all trees in each plot, we measured 11 functional stem and leaf traits related to flooding tolerance and avoidance, and nutrient use. We hypothesized that (i) traits related to resource use will reflect the fast-slow spectrum, where white-water forests growing in resource-rich environments will have traits related to resource acquisition and fast growth (i.e., higher leaf area per unit leaf mass) and black-water forests growing in resource-poor environments will have traits related to resource conservation and high survival but slow growth (i.e., higher wood density). (ii) Within each forest, there is a gradient in flooding duration and depth, where low levels of flooding will lead to communities with flood avoidance traits (i.e., lighter woods and taller plants). At high levels of flooding, such an avoidance strategy will not be feasible anymore, leading to communities with flood tolerance traits (i.e., higher stem lenticel density and deciduousness). iii) The combination of low nutrients and higher flooding characterizing harsh environments (i.e., low topographies of black-water forests) may either lead to stronger environmental filtering and reduced trait variation, or alternatively to more trait variation because of the presence of alternative functional designs in the same community (Dias et al. 2020).

\section{Methods}

Study area

Our study was conducted in the Mamirauá Sustainable Development Reserve (MSDR) and in the Uatumã Sustainable Development Reserve (USDR), located in Central Amazonia (Fittkau 1971) (Fig. 1). Central Amazonia has a typical hot and humid tropical climate. Mean annual temperature is $26.6^{\circ} \mathrm{C}$, and mean annual precipitation is $2100 \mathrm{~mm} / \mathrm{y}$, with a wet season occurring from December to April and a dry season from June to October (Fittkau 1971). Soils are mainly derived from rocks and sediments from tertiary heavily leached and low in mineral nutrients (Irion 1978), but Central Amazonia floodplain forests differ on soil fertility as a reflection of distinct geomorphological formation (Sioli 1984). Floodplain forests are subjected to a seasonal and monomodal flood pulse which leads the flooding of the adjacent forests every year (Junk et al. 1989).

The Mamirauá Reserve $\left(2^{\circ} 51^{\prime} \mathrm{S} 64^{\circ} 55^{\prime} \mathrm{W}\right)$ has an area of $124,000 \mathrm{~km}^{2}$ covered by preserved white-water floodplain forests and is adjacent to the Japurá and Solimões River and the Auati-paranã Channel (IDSM 2010). Our study was developed at the Jarauá River. The Uatumã Reserve $\left(1^{\circ} 48^{\prime} \mathrm{S}, 59^{\circ} 15^{\prime} \mathrm{W}\right)$ has an area of $4244 \mathrm{~km}^{2}$ with upland forests, black-water floodplain forests, and savannas. Our study was developed at the Abacate River, one of the main tributaries of Uatumã River which runs adjacent to it, draining the Abacate basin. Its floodplain forest is mostly preserved with only small fishery communities living at the mouth of Abacate River (IDESAM 2009).

\section{Sampling}

Fieldwork was carried out under collecting permits 015/2016-DEMUC/SEMA (Department of Climate Change and Management of Protected Areas of Secretary of Amazonas State for the Environment) and SISBIO 52109-1 (Chico Mendes Institute for Biodiversity Conservation, ICMBio). We established 40 plots of $25 \times 25 \mathrm{~m}\left(625 \mathrm{~m}^{2}\right), 20$ plots in each forest type (white-water and black-water forest) along a flooding gradient.

To evaluate community functional traits, we used an individual-based approach, in which all individuals in a plot were measured with a stem diameter $\geq 10 \mathrm{~cm}$. In this way, intraspecific trait variation is taken into account, as it is the traits of the phenotype that should determine local community assembly (Violle et al. 2012). We measured 1110 individuals in total, 437 in white-water forest and 673 in blackwater forest. For each individual, we measured 11 traits that are relevant for flooding tolerance/avoidance and for resource acquisition and use (Table 1) following standardized trait protocols (Cornelissen et al. 2003; Pérez-Harguindeguy et al. 2013). Plant height, stem diameter (at $1.30 \mathrm{~m}$ ), lenticel density, and chlorophyll content were measured, and leaf and wood samples were collected for further analyses. Leaf traits were measured for five sun-exposed leaves per individual, and wood traits were measured for one branch per individual. In the laboratory, we calculated height-to-diameter ratio and measured branch wood density, leaf area, specific leaf area, and leaf dry matter 


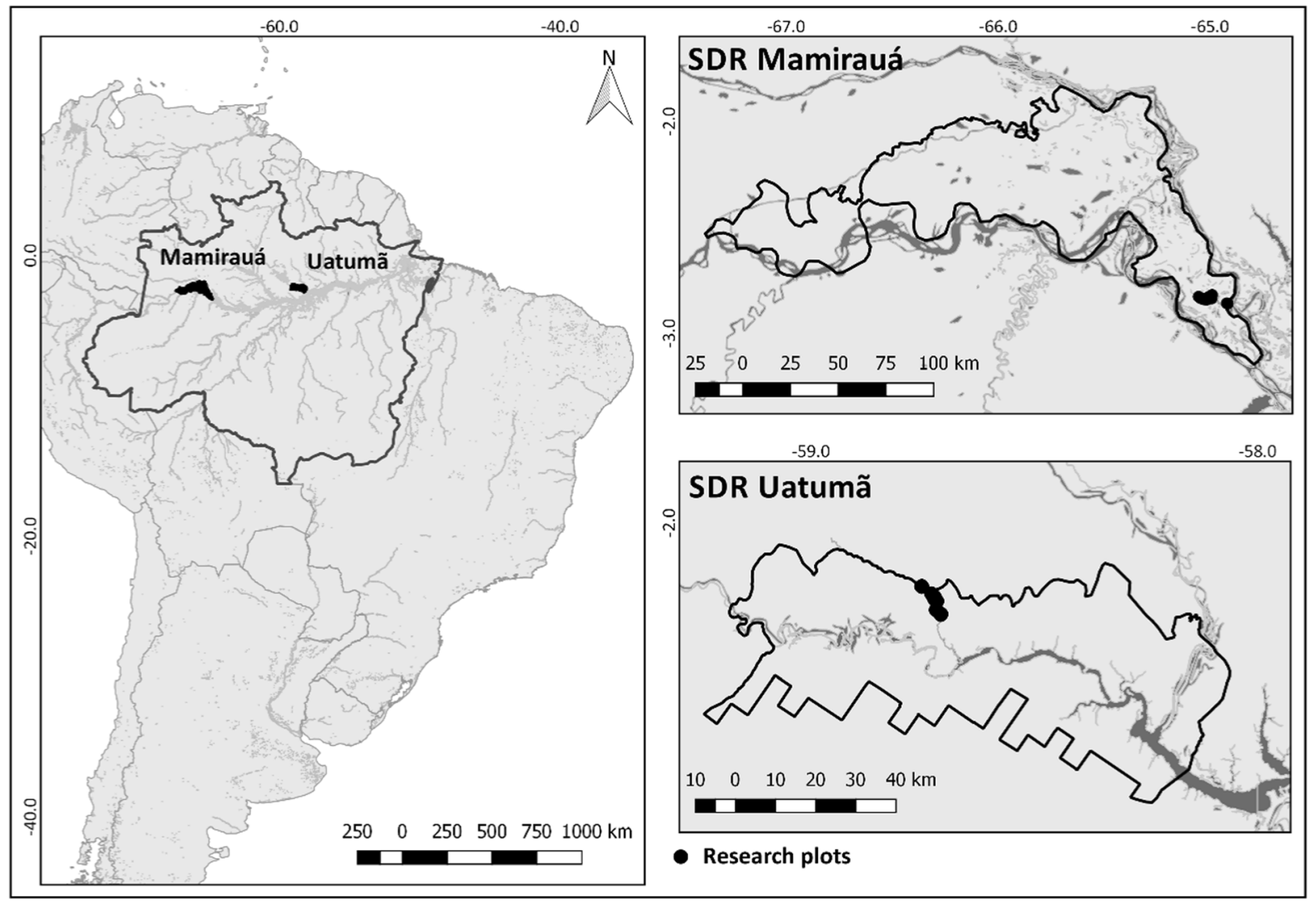

Fig. 1 Location of study areas Mamirauá and Uatumã reserves (left side) and research plots (right side) in Central Amazonia, Brazil

Table 1 Overview of eleven plant functional traits included in this study, with the trait name, units, and their function

\begin{tabular}{|c|c|c|}
\hline Plant functional trait & Function related & References \\
\hline Leaf area $\left(\mathrm{cm}^{2}\right)$ & Light intercepting area, respiration, transpiration, gas exchange & (Lebrija-Trejos et al. 2010) \\
\hline Specific leaf area $\left(\mathrm{cm}^{2} \mathrm{~g}^{-1}\right)$ & $\begin{array}{l}\text { Light capture economics, net assimilation rate, relative growth } \\
\text { rate, leaf life span, photosynthetic capacity }\end{array}$ & $\begin{array}{l}\text { (Lavorel and Garnier 2002; } \\
\text { Poorter et al. 2006) }\end{array}$ \\
\hline $\begin{array}{l}\text { Chlorophyll content (SPAD } \\
\text { units) }\end{array}$ & Light uptake efficiency, photosynthetic rates & (Poorter et al. 2006) \\
\hline $\begin{array}{l}\text { Leaf dry matter content } \\
\left(\mathrm{g} \mathrm{g} \mathrm{g}^{-1}\right)\end{array}$ & $\begin{array}{l}\text { Construction costs, nutrient retention, resistance against } \\
\text { herbivory, and physical damage, drought resistance }\end{array}$ & $\begin{array}{l}\text { (Lavorel and Garnier 2002; } \\
\text { Lebrija-Trejos et al. 2010) }\end{array}$ \\
\hline $\begin{array}{l}\text { Leaf nitrogen, phosphorus, } \\
\text { and potassium }\left(\mathrm{g} \mathrm{kg}^{-1}\right)\end{array}$ & Photosynthetic rates, $\mathrm{CO}_{2}$ assimilation, leaf nutrient levels & (Wright et al. 2004; Reich 2014) \\
\hline $\begin{array}{l}\text { Phenology (semi/deciduous or } \\
\text { evergreen, \%) }\end{array}$ & Drought avoidance or flooding stress avoidance & (Lebrija-Trejos et al. 2010) \\
\hline $\begin{array}{l}\text { Branch wood density } \\
\qquad\left(\mathrm{g} \mathrm{cm}^{-3}\right)\end{array}$ & $\begin{array}{l}\text { Construction costs, growth rate, pathogen resistance, mortality } \\
\text { rate }\end{array}$ & $\begin{array}{l}\text { (Swenson and Enquist 2008; } \\
\text { Chave et al. 2009) }\end{array}$ \\
\hline $\begin{array}{l}\text { Lenticel density (count in } \\
10 \mathrm{~cm}^{2} \text { ) }\end{array}$ & Oxygen uptake, gas exchange & (Parolin and Wittmann 2010) \\
\hline $\begin{array}{l}\text { Height-to-diameter ratio } \\
\qquad\left(\mathrm{m} \mathrm{cm}^{-1}\right)\end{array}$ & Stability, competitive strength & $\begin{array}{l}\text { (Opio et al. 2000; Chave et al. } \\
\text { 2009) }\end{array}$ \\
\hline
\end{tabular}


content. Collected branches (including bark) were put into water, and its fresh volume was measured by the water displacement method. The leaves were individually detached (excluding petiole) for measurements of fresh mass and dimension, the latter, obtained in a portable scanner and analyzed with the ImageJ software. For dry mass, leaves were oven dried for $48 \mathrm{~h}$ at $60^{\circ} \mathrm{C}$, and branches were dried for $72 \mathrm{~h}$ at $102{ }^{\circ} \mathrm{C}$. Chlorophyll content was measured for three leaves with a Chlorophyll Meter (SPAD 502) and subsequently mean values per tree were calculated. Leaf nitrogen, phosphorus, and potassium concentrations were measured by the Brazilian Agriculture Research Company (Embrapa, Manaus) (Embrapa Solos 2000). We classified species' leaf phenology habit as (semi)deciduous or evergreen based on available data from the literature (Parolin et al. 2002; da Silva Marinho et al. 2010; Wittmann et al. 2010a) and calculated the percentage of occurrence per plot (60\% and $44 \%$ of species were classified in whitewater and black-water forest, respectively).

In each plot, we collected a composite soil sample of the first $10 \mathrm{~cm}$ of topsoil (excluding the litter layer). Substrate samples were analyzed at the EMBRAPA Soil laboratory in Manaus. We analyzed the variables: percentage of sand, silt, and clay; total nitrogen concentration (Kjeldahl method, distillation); phosphorus availability $\left(\mathrm{P}^{+}\right)$, exchangeable sodium $\left(\mathrm{Na}^{+}\right)$, potassium $\left(\mathrm{K}^{+}\right)$, iron $\left(\mathrm{Fe}^{2+}\right)$, zinc $\left(\mathrm{Zn}^{2+}\right)$, manganese $\left(\mathrm{Mg}^{2+}\right)$, and copper $\left(\mathrm{Cu}^{2+}\right)$ (Mehlich-1 method); exchangeable calcium $\left(\mathrm{Ca}^{2+}\right)$, magnesium $\left(\mathrm{Mg}^{2+}\right)$, and aluminum $\left(\mathrm{Al}^{2+}\right)$ (extractor $\mathrm{KCl}$ at $1 \mathrm{ml} . \mathrm{L}^{-1}$ ); cation-exchange capacity (CEC, sum of cations plus acidity); total organic carbon (Walkley-Black method); and $\mathrm{pH}$ (measured through and electrode immersed in a solution with a 1:2.5 ratio of soil to distilled water). Further details can be found in Embrapa Solos (1997).

We calculated the mean flood duration (hydroperiod in days year ${ }^{-1}$ ) of each plot using the maximum flood marks (meters) of the last high-water period on trunks relative to the daily water levels, provided by Brazilian National Water Agency (ANA; 1982-2011 for white water and 1974-2015 for black water). The maximum flood marks were measured for all trees and calculated the mean value per plot (flooding depth per plot) (Wittmann and Junk 2003). Flooding depth and hydroperiod ranged from $1.7 \mathrm{~m}$ and 153 days to $6.4 \mathrm{~m}$ and 288 days in white-water forests and from $0.5 \mathrm{~m}$ and 39 days to $4.9 \mathrm{~m}$ and 159 days in black-water forests (Fig. 1 in Supplementary material).

Data analyses

We used community functional trait mean and kurtosis for each trait measured in the plots. A high kurtosis value indicates lower trait variation in the plot (Enquist et al. 2015). We tested correlation between traits and environmental variables using Pearson' correlation to avoid multicollinearity in regression analysis (Gotelli and Elison 2010).

To describe the variation in functional composition and diversity across the plots, we carried out two principal component analyses (PCA): one using the community mean values of the 11 traits and another using the 11 trait kurtosis values per plot. To facilitate visual interpretation, we classified the plots based on their flooding depth values following (Wittmann et al. 2002) classification, which describes high and low flooding based on changes in species composition and forest structure along the gradient. High flooding in white-water plots was considered when up to $3 \mathrm{~m}$ and for black-water forest up to $1.3 \mathrm{~m}$. To analyze how environmental filters affect functional composition (i.e., mean trait values) and functional diversity (i.e., Kurtosis values) of the communities, we built two multiple linear regression models by regressing the first PCA axis scores on the environmental factors to compare the effects of edaphic and flooding gradients (Gotelli and Elison 2010; le Bagousse-Pinguet et al. 2017). We included environmental predictors in the model with a variance inflation factor below 10 . The first model combined both flooding and soil variables: hydroperiod, phosphorus, and aluminum. The second model included only soil variables: cation-exchange capacity, phosphorus, and aluminum. We selected cations and phosphorus because they are important to plant metabolism and growth (Chapin 1980), aluminum because it is a highly concentrated element in the Amazonian soils and related to plant distribution (Quesada et al. 2011; Brunner and Sperisen 2013) and hydroperiod because it describes both flooding depth and duration. We used model selection based on Akaike information criterion (AIC). Because some white-water plots experienced very high flooding depth (5-6 $\mathrm{m}$ of flooding), we rebuilt the models without these extreme plots to control for possible bias. All analyses were carried out using the $\mathrm{R}$ 
platform v 3.3.3 (R development Core Team www.Rproject.org).

\section{Results}

Functional traits distribution in white- and blackwater forests

Functional trait mean values of floodplain tree communities varied across plots and especially between white- and black-water forest types (Fig. 2). The first PCA axis explained $54 \%$ of the variation in community mean trait values. White-water tree communities with larger leaf area, higher specific leaf area, leaf nitrogen, phosphorus and potassium concentrations, and larger proportion of deciduous trees were located to the right side of the first PCA axis, and black-water tree communities with higher leaf dry matter content, leaf chlorophyll content, branch wood density, lenticel density, and a larger proportion of evergreen trees

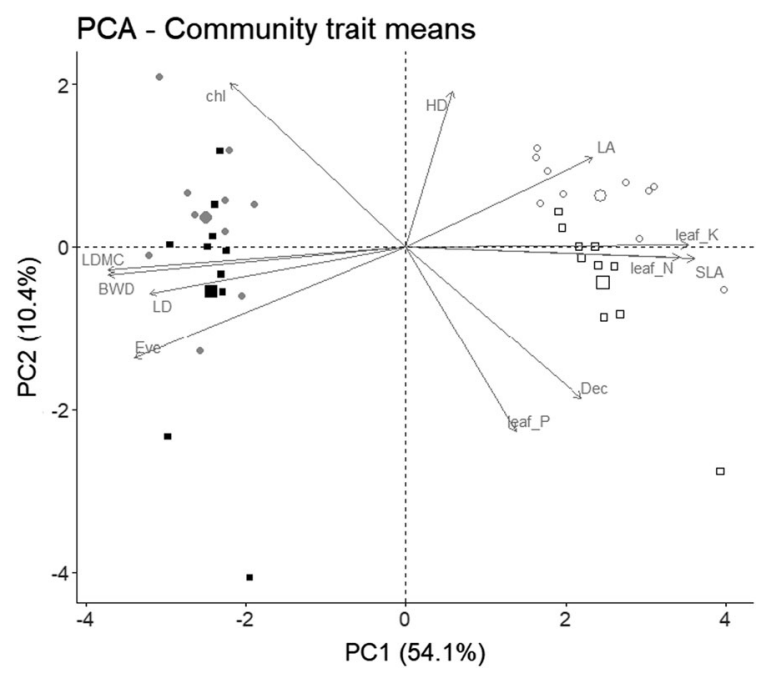

Fig. 2 Principal component analysis (PCA) of 11 functional trait mean values of white-water (várzea) and black-water (igapo') tree communities' ( $N=40$ plots) that experience high and low flooding depths and duration. White symbols indicate white-water plots and black and gray symbols indicate blackwater plots. Circles indicate low flood depths and squares indicate high flood depths. The size of the symbols indicates plots contributions in the analysis. Leaf area (LA), specific leaf area (SLA), leaf dry matter content (LDMC), leaf chlorophyll content (Chl), leaf nitrogen (Leaf_N), leaf phosphorus (leaf_P), leaf potassium (leaf_K), branch wood density (BWD), lenticel density (LD), height-to-diameter ratio (HD), and phenology (deciduous, Dec and evergreen, Eve) are shown were concentrated to the left side of the axis. The second PCA axis explained $10.4 \%$ of the variation and was associated with flooding depth, which had a more pronounced effect on the functional composition of white- compared to black-water communities. In white-water forests, lower flooding was related with high H:D ratio and larger leaves, whereas higher flooding was associated with deciduous trees and higher leaf phosphorus content. Flooding depth did not have a clear effect on the functional traits mean values of black-water communities.

For functional trait variation, the first PCA axis explained $19.4 \%$ of the variation in kurtosis of the communities, with communities with high kurtosis (and hence, low variation) in leaf phosphorous and lenticel density to the right (Fig. 3). The second axis explained $18.7 \%$ of the variation with communities with high kurtosis in specific leaf area, leaf area, and leaf dry matter content at the top. Plots belonging to

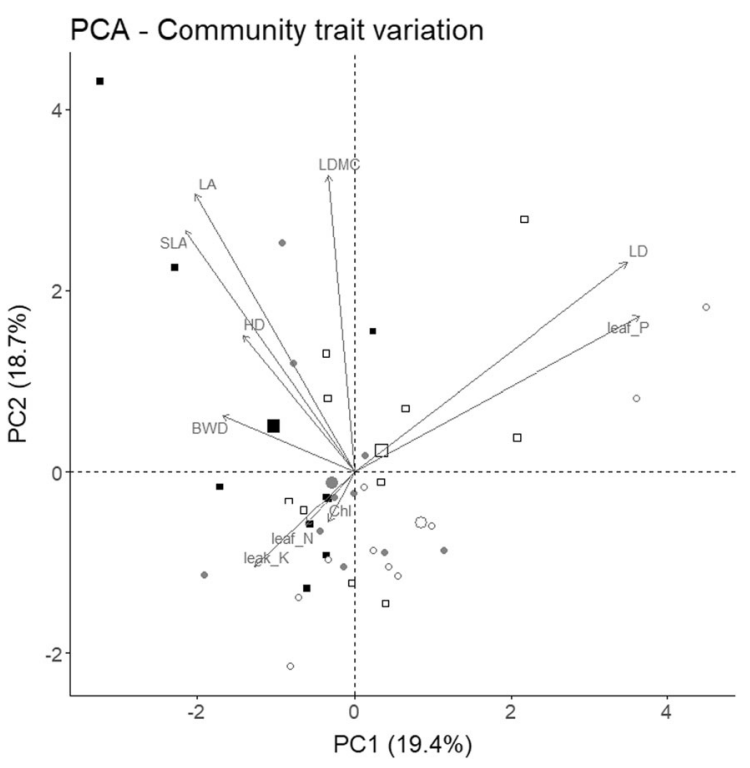

Fig. 3 Principal component analysis (PCA) of 11 functional kurtosis trait values of white-water (várzea) and black-water (igapo) ) tree communities' ( $N=40$ plots) that experience high and low flooding depths and duration. White symbols indicate white-water plots and black and gray symbols indicate blackwater plots. Circles indicate low flood depths, and squares indicate high flood depths. The size of the symbols indicates plots contributions in the analysis. Leaf area (LA), specific leaf area (SLA), leaf dry matter content (LDMC), leaf chlorophyll content (Chl), leaf nitrogen (Leaf_N), leaf phosphorus (leaf_P), leaf potassium (leaf_K), branch wood density (BWD), lenticel density (LD), height-to-diameter ratio (HD), and phenology (deciduous, Dec and evergreen, Eve) are shown 
Table 2 Multiple linear regression of PCA first axis (traits mean values) in relation to environmental variables

\begin{tabular}{llcrcr}
\hline Regression model & Environmental variable & $\beta$-coefficient & $P$ & $\mathrm{R}^{2}{ }_{\text {adj }}$ & $P$ \\
\hline Model 1 & Hydroperiod & 0.75 & $<0.01$ & 0.8 & $<0.01$ \\
& Phosphorus & 0.29 & $<0.01$ & & \\
Aluminum & -0.02 & 0.85 & & \\
Model 2 & Cation-exchange capacity & 0.79 & $<0.01$ & 0.9 & $<0.01$ \\
& Phosphorus & 0.22 & $<0.01$ & & 34 \\
& Aluminum & 0.14 & 0.03 & & \\
\hline
\end{tabular}

Model 1 includes flood and edaphic variables: hydroperiod, soil phosphorus, and aluminum; model 2 includes edaphic variables: cation-exchange capacity, phosphorus, and aluminum. The columns show the standardized regression ( $\beta$-coefficient) and significance $(P)$, adjusted coefficient of determination $\left(R^{2}\right.$ adj, significance $\left.(P)\right)$, and Akaike Information Criterion of the model

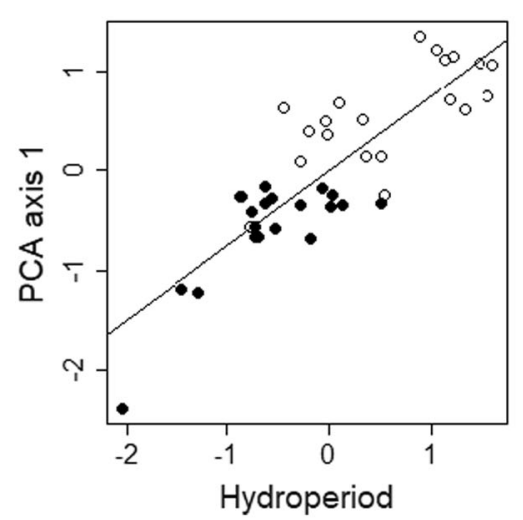

Fig. 4 Partial regressions of functional composition (mean values PCA first axis) and environmental characteristics: hydroperiod, soil phosphorus, and aluminum of white-water forests (white dots) and black-water forests (black dots). Higher

different forest types and flooding depths did not differ clearly in their position on these two PCA axes (Fig. 3).

Edaphic characteristics and flooding affect functional trait distribution

The mean values of multivariate traits were related to edaphic characteristics and flooding. Model 1 (with hydrological and edaphic variables) indicated that an increase in soil phosphorus and hydroperiod was associated with communities with more 'productive' traits (i.e., high scores on PCA 1), as reflected in high SLA, leaf nutrient concentrations, and a deciduous leaf habit (Table 2; Fig. 4). Model 2 (only with edaphic variables) indicated that an increase in soil cations, phosphorus, and aluminum also was associated to communities with more productive traits (i.e.,

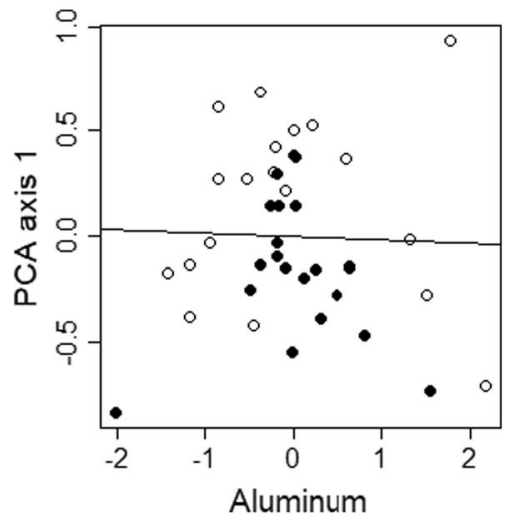

values of the PCA first axis indicate higher community mean values of specific leaf area, leaf potassium and leaf nitrogen, and lower community mean values of leaf dry matter content, branch wood density, lenticel density, and evergreen species

high PCA1 scores, Table 2; Fig. 5). Model 2 was more robust than model 1 as it had a lower Akaike Information Criterion (34 vs. 50) and explained more of the mean community-trait variation $\left(r^{2}=0.88\right.$ vs. 0.82 ). This means that soil characteristics had a stronger influence on trait mean values than the combination of soil and flooding. The analyses excluding the high flooding depths in white-water forests showed the same as the previous one, indicating that besides differences in flooding among white and black water, soil properties have a stronger effect on traits values (Table 2; Figs. 2 and 3 in Supplementary material). Functional trait variation was not significantly related to environmental variables, confirming the PCA that showed little variation of functional kurtosis across plots. 


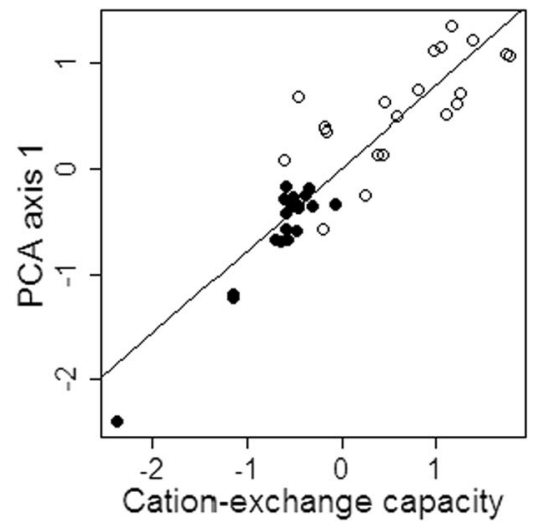

Fig. 5 Partial regressions of functional composition (mean values PCA first axis) and environmental characteristics: total exchangeable bases, soil phosphorus, and aluminum of whitewater forests (white dots) and black-water forests (black dots). Higher values of the PCA first axis indicate higher community

\section{Discussion}

We evaluated how gradients in soil fertility and flooding stress affect trait means and variation in Amazonian floodplain forests and found that functional trait means were mainly driven by soil cation and phosphorus concentrations, differentiating whiteand black-water forests by their trait values, whereas trait variation was not affected by the measured environmental conditions.

White-water forests have acquisitive traits and black-water forests conservative traits

The principal component analysis showed that whitewater communities had larger leaf area, higher specific leaf area, and leaf nutrient concentrations (Fig. 2), which collectively increase light capture, photosynthetic capacity, carbon gain, and growth rate (Lavorel and Garnier 2002; Reich et al. 2003; Poorter et al. 2006). Black-water communities were characterized by higher leaf dry matter content, wood density, and a larger proportion of evergreen species (Fig. 2). These traits increase tissue resistance against biophysical hazards and tissue longevity, and contribute, therefore, to the conservation of resources (Parolin and Worbes 2000; Kitajima and Poorter 2008). Hence, these Amazonian floodplain forests show a "fast-slow" spectrum in ecological strategies, ranging from resource acquisition versus resource conservation, as described for other plant communities worldwide

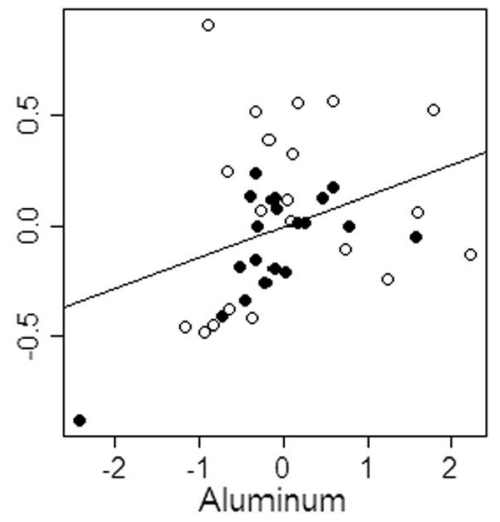

mean values of specific leaf area, leaf potassium and leaf nitrogen, and lower community mean values of leaf dry matter content, branch wood density, lenticel density, and evergreen species

(Díaz et al. 2004; Wright et al. 2004; Reich 2014). In these flooded forest communities, wood and leaf traits co-varied in concert along this spectrum and did not show independent axis of variation, as has been found for upland forest in French Guiana (Baraloto et al. 2010). Perhaps in these flooded forests, extreme nutrient and oxygen stress require a stronger alignment of stem and leaf traits compared to these upland forests.

Soil fertility is a strong driver of functional traits mean values of floodplain communities

The multiple regression analysis also confirmed that soil fertility (base cations, and to a lesser extent phosphorus and aluminum) had the strongest effect on functional trait mean values of floodplain communities. Base cations are important bioelements that accumulate in the vegetation and are related to biological processes, like photosynthesis and plant growth (Karin Furch 1997). Calcium, for example, which is a limiting nutrient in the upland forest of the Amazon region (Quesada et al. 2011), was especially higher in white-water forest and can be an important component driving trait variation (Ferguson 1984; Moran et al. 2000). Phosphorus is often identified as a limiting element on the old, weathered soils from Amazonia and the Guiana shield, and is a strong driver of community dynamics in upland Amazonian forest (Quesada et al. 2011). Aluminum can be toxic, especially in tropical systems with a low $\mathrm{pH}$ (Moran 
et al. 2000; Brunner and Sperisen 2013). Aluminum ions occur in high concentration in the Amazon region, but its potential toxicity for plants is not well understood (Herrera et al. 1978; Quesada et al. 2011). Wood plants native to acid soils evolved various strategies to deal with aluminum stress (Brunner and Sperisen 2013), perhaps acquisitive tree species may adapt to high aluminum concentration by accumulating it in their leaves.

Flooding intensity has little effect on functional traits mean values

Flooding intensity is often found to be the main environmental factor that determines species distribution in floodplain forests (Wittmann et al. 2006; Assis et al. 2015). We hypothesized, therefore that communities with low flood depth and duration would have flood avoidance traits (i.e., fast height growth and slender stems) and communities with high flood depth and duration would have flood tolerance traits (i.e., high wood density and lenticel density). Yet, in our study, flooding depth only affected white-water forests where higher flooding depths favored communities with a deciduous leaf habit and smaller leaves (Fig. 2). A deciduous leaf habit may allow species to be relatively inactive during the anoxic period, and small leaves are a general adaptation to (flooding) stress (Parolin et al. 2002; Schöngart et al. 2002). Perhaps the high soil fertility of white-water forests also facilitates a deciduous response to flooding stress, as nutrients lost during shedding can be easily replaced.

The multiple regression analysis showed that length of the hydroperiod significantly affected community functional properties where a longer inundation time, surprisingly, leads to more acquisitive trait values (Table 2). Perhaps, an increase in flooding duration also increases the nutrient supply to the soil through sedimentation (Wittmann et al. 2004; Junk et al. 2011). Although both hydroperiod and soil fertility can be correlated to some extent, our most parsimonious model shows that soil properties rather than flooding are the main determinant of functional composition in floodplain tree communities (Table 2).
Soil resources and flooding stress do not affect trait variation of floodplain communities

We hypothesized that harsher environmental conditions (low nutrients and higher flooding) would either lead to stronger environmental filtering and reduced trait variation in communities, or to larger trait variation because of alternative designs. Our results show that floodplain communities may differ in their trait variation, but that this is not related to forest types or any of the environmental factors evaluated.

In support of the hypotheses, we indeed found that fertile white-water forests had higher taxonomic diversity than black-water forests in our study (i.e., Fisher's alpha diversity) (Junk et al. 2011, 2015), although species richness was similar (Tables 4 and 5 in Supplementary material). Functional and taxonomic diversity can vary independently, which means that the conditions that can support species coexistence may not support their functional differentiation (Bello et al. 2006). Further investigation is needed to better understand the role of these two environmental filters on functional trait variation of floodplain trees, especially along the flooding gradient.

\section{Conclusions}

Floodplain forests are important ecosystems of Amazonian landscape, and their biological communities are closely related to water dynamics, which can be especially affected by environmental changes. Despite being still poorly studied, the ecological mechanisms that shape the assemblages of tree communities are essential to improve their conservation. Here, we show that the environmental filtering of soil characteristics is a strong mechanism that selects different ecological strategies in white- and black-water forests. Amazonian floodplain forests differed in their functional trait mean values. Productive leaves and fast-growth traits were found in nutrient-rich white-water forests, and strong tissues and slow-growth traits were more associated with nutrient-poor black-water forest, in line with the 'fast-slow' spectrum of ecological strategies along an edaphic properties gradient. Functional trait variation had no relation to environmental gradients. Edaphic characteristics, especially soil cations, seem to act as a strong environmental filter leading to trait convergence in floodplain tree 
communities. Floodplain forests harbor a great species diversity of trees with strategies to deal with seasonal flooding, but they can differ widely in their growth strategy. This information is important because these strategies can indicate forest response to environmental changes, their regeneration, and recovery capacity, which can improve floodplain forest management and conservation.

Acknowledgements We want to thank all the people of Jarauá (Mamirauá reserve) and Abacate (Uatumã reserve) for their hospitality and assistance during fieldwork.

Funding Gisele Biem Mori was supported by a research grant from Conselho Nacional de Desenvolvimento Científico e Tecnológico (CNPq, Brazil, 140069/2015-1), Coordenação de Aperfeiçoamento de Pessoal de Nível Superior (PDSE/CAPES, Brazil. 88881.134479/2016-01). Fieldwork was supported by MAUA Long-term Project-PELD (CNPq/FAPEAMFundação de Amparo à Pesquisa do Amazonas, 441590/20160), and Estudos das Adaptações da Biota Aquática da Amazônia (INCT-ADAPTA II, CNPq 465540/2014-7).

Data availability All data are available as a supplementary material.

\section{Compliance with ethical standards}

Conflict of interest The authors declare there is no conflict of interest.

\section{References}

Assahira C, Teresa M, Piedade F, Trumbore SE, Wittmann F, Barçante B, Cintra L, Silva E, Faria A, Resende D, Schöngart J (2017) Forest Ecology and Management Tree mortality of a flood-adapted species in response of hydrographic changes caused by an Amazonian river dam. For Ecol Manag 396:113-123. https://doi.org/10.1016/j. foreco.2017.04.016

Assis RL, Haugaasen T, Schöngart J, Montero JC, Piedade MTF, Wittmann F (2015) Patterns of tree diversity and composition in Amazonian floodplain paleo-várzea forest. J Veg Sci 26:312-322. https://doi.org/10.1111/jvs.12229

Baraloto C, Timothy Paine CE, Patiño S, Bonal D, Hérault B, Chave J (2010) Functional trait variation and sampling strategies in species-rich plant communities. Funct Ecol 24:208-216. https://doi.org/10.1111/j.1365-2435.2009. 01600.x

Bernard-Verdier M, Navas ML, Vellend M, Violle C, Fayolle A, Garnier E (2012) Community assembly along a soil depth gradient: contrasting patterns of plant trait convergence and divergence in a Mediterranean rangeland. J Ecol 100:1422-1433. https://doi.org/10.1111/1365-2745.12003
Brunner I, Sperisen C (2013) Aluminum exclusion and aluminum tolerance in woody plants. Front Plant Sci 4:1-12. https://doi.org/10.3389/fpls.2013.00172

Chapin FS (1980) The mineral nutrition of wild plants. Funct Plant Biol 28:897-906

Chave J, Coomes D, Jansen S, Lewis SL, Swenson NG, Zanne AE (2009) Towards a worldwide wood economics spectrum. Ecol Lett 12:351-366. https://doi.org/10.1111/j. 1461-0248.2009.01285.x

Cornelissen JHC, Lavorel S, Garnier E, Díaz S, Buchmann N, Gurvich DE, Reich PB, ter Steege H, Morgan HD, van der Heijden MGA, Pausas JG, Poorter H (2003) A handbook of protocols for standardised and easy measurement of plant functional traits worldwide. Aust J Bot 51:335-380. https:// doi.org/10.1071/BT02124

Cornwell WK, Ackerly DD (2009) Community assembly and shifts in plant trait distributions across an environmental gradient in coastal California. Ecol Monogr 79:109-126. https://doi.org/10.1890/07-1134.1

da Silva Marinho TA, Piedade MTF, Wittmann F (2010) Distribution and population structure of four Central Amazonian high-várzea timber species. Wetlands Ecol Manage 18:665-677. https://doi.org/10.1007/s11273-0109186-y

de Bello F, Leps J, Sebastià M (2006) Variations in species and functional plant diversity along climatic and grazing gradients. Ecography 29:801-810

de Resende AF, Schöngart J, Streher AS, Ferreira-Ferreira J, Piedade MTF, Silva TSF (2019) Massive tree mortality from flood pulse disturbances in Amazonian floodplain forests: the collateral effects of hydropower production. Sci Total Environ 659:587-598. https://doi.org/10.1016/j. scitotenv.2018.12.208

de Simone O, Müller E, Junk WJ, Schmidt W (2002) Adaptations of Central Amazon tree species to prolonged flooding: root morphology and leaf longevity. Plant Biology 4:515-522. https://doi.org/10.1055/s-2002-34127

Dias ATC, Rosado BHP, de Bello F, Pistón N, de Mattos EA (2020) Alternative plant designs: consequences for community assembly and ecosystem functioning. Ann Bot 125:391-398. https://doi.org/10.1093/aob/mcz180

Díaz S, Hodgson JG, Thompson K, Cabido M, Cornelissen JHC, Jalili A, Montserrat-Martí G, Grime JP, Zarrinkamar F, Asri Y, Band SR, Basconcelo S, Castro-Díez P, Funes G, Hamzehee B, Khoshnevi M, Pérez-Harguindeguy N, Pérez-Rontomé MC, Shirvany A, Vendramini F, Yazdani S, Abbas-Azimi R, Bogaard A, Boustani S, Charles M, Dehghan M, de Torres-Espuny L, Falczuk V, GuerreroCampo J, Hynd A, Jones G, Kowsary E, Kazemi-Saeed F, Maestro-Martínez M, Romo-Díez A, Shaw S, Siavash B, Villar-Salvador P, Zak MR (2004) The plant traits that drive ecosystems: evidence from three continents. J Veg Sci 15:295. https://doi.org/10.1658/11009233(2004)015[0295:TPTTDE]2.0.CO;2

Enquist BJ, Norberg J, Bonser SP, Violle C, Webb CT, Henderson A, Sloat LL, Savage VM (2015) Scaling from traits to ecosystems: developing a general trait driver theory via integrating trait-based and metabolic scaling theories, 1st edn. Elsevier, Amsterdam

Ferguson LB (1984) Calcium in plant senscence and fruit ripening. Plant Cell Environ 7:477-489 
Fittkau EJ (1971) Esboço de uma divisão ecológica da região amazônica. In: Proc Symp Biol Trop Amaz. Florencia y Leticia, pp 363-372

Flores BM, Holmgren M, Xu C, van Nes EH, Jakovac CC, Mesquita RCG, Scheffer M (2017) Floodplains as an Achilles' heel of Amazonian forest resilience. Proc Natl Acad Sci 114:4442-4446. https://doi.org/10.1073/pnas. 1617988114

Furch K (1997) Chemistry of várzea and igapó soils and nutrient inventory of their floodplain forests. In: Junk WJ (ed) The Central Amazon floodplain: ecology of a pulsing system. Springer Verlag, Berlin, pp 47-68

Gotelli NJ, Elison AM (2010) Princípios de Estatística em Ecologia, 1st edn. Artmed, Porto Alegre

Grime JP (2006) Trait convergence and trait divergence in herbaceous plant communities: mechanisms and consequences. J Veg Sci 17:255-260. https://doi.org/10.1111/j. 1654-1103.2006.tb02444.x

Herrera R, Jordan CF, Klinge H, Medina E (1978) Amazon ecosystems. Their structure and functioning with particular emphasis on nutrients. Interciencia 3:223-232

IDESAM I de C e DS do A (2009) Série Técnica Planos de Gestão Reserva de Desenvolvimento Sustentável do Uatumã Volumes 1 e 2. 1-2:150

IDSM (2010) Plano de Gestão Reserva de Desenvolvimento Sustentável Mamirauá. MCTI/IDSM-OS, Tefé

Irion $\mathrm{G}$ (1978) Soil infertility in the Amazonian rain forest. Naturwissenschaften 65:515-519. https://doi.org/10.1007/ BF00439791

Junk WJ, Bayley PB, Sparks RE (1989) The floodpulse concept in the river-floodplain systems. Canadian Special Publ Fish Aquat Sci 106:110-127

Junk WJ, Piedade MTF, Schöngart J, Cohn-Haft M, Adeney JM, Wittmann F (2011) A classification of major naturallyoccurring amazonian lowland wetlands. Wetlands 31:623-640. https://doi.org/10.1007/s13157-011-0190-7

Junk WJ, Wittmann F, Schöngart J, Piedade MTF (2015) A classification of the major habitats of Amazonian blackwater river floodplains and a comparison with their whitewater counterparts. Wetlands Ecol Manag 23:677-693. https://doi.org/10.1007/s11273-015-9412-8

Keddy PA (1992) Assembly and response rules: two goals for predictive community ecology. J Veg Sci 3:157-164. https://doi.org/10.2307/3235676

Kitajima K, Poorter L (2008) Functional basis for resource niche partitioning by tropical trees. Tropical forest community ecology. Blackwell Science, Hoboken, pp 160-181

Lavorel S, Garnier E (2002) Predicting changes in community composition and ecosystem functioning from plant traits: revisting the Holy Grail. Funct Ecol 16:545-556. https:// doi.org/10.1046/J.1365-2435.2002.00664.X

le Bagousse-Pinguet Y, Gross N, Maestre FT, Maire V, de Bello F, Fonseca CR, Kattge J, Valencia E, Leps J, Liancourt P (2017) Testing the environmental filtering concept in global drylands. J Ecol 105:1058-1069. https://doi.org/10. 1111/1365-2745.12735

Lebrija-Trejos E, Pérez-García EA, Meave JA, Bongers F, Poorter AL (2010) Functional traits and environmental filtering drive community assembly in a species-rich tropical system. Ecology 91(2):386-398
Lobo PC, Joly CA (1998) Tolerance to hypoxia and anoxia in neotropical tree species. Oecol Bras 4:137-156

Macarthur R, Levins R (1967) The limiting similarity, convergencem and divergence of coexisting species. Am Nat 101:377-385

McGill BJ, Enquist BJ, Weiher E, Westoby M (2006) Rebuilding community ecology from functional traits. Trends Ecol Evol 21:178-185. https://doi.org/10.1016/j. tree.2006.02.002

Melack JM, Hess LL (2010) Remote sensing of the distribution and extent of wetlands in the Amazon basin. In: Junk WJ, Piedade MTF, Wittmann F, Schöngart J, Parolin P (eds) Amazonian floodplain forests: ecophysiology, biodiversity and sustainable management (ecological studies). Springer, Berlin, pp 43-59

Moran EF, Brondizio ES, Tucker JM, Clara da Silva-Forsberg M, McCracken S, Falesi I, Rudy Professor of Anthropology JH, Professor of Anthropology A, Director A (2000) Effects of soil fertility and land-use on forest succession in Amazônia. For Ecol Manag 139:93-108

Mori GB, Schietti J, Poorter L, Piedade MTF (2019) Trait divergence and habitat specialization in tropical floodplain forests trees. PLoS ONE 14:1-14. https://doi.org/10.1371/ journal.pone.0212232

Opio C, Jacob N, Coopersmith D (2000) Height to diameter ratio as a competition index for young conifer plantations in northern British Columbia, Canada. For Ecol Manage 137:245-252. https://doi.org/10.1016/S03781127(99)00312-6

Parolin P, Wittmann F (2010) Struggle in the flood: tree responses to flooding stress in four tropical floodplain systems. AoB Plants 2010:plq003. https://doi.org/10.1093/ aobpla/plq003

Parolin P, Worbes M (2000) Wood density of trees in black water floodplains of Rio Jau National Park, Amazonia, Brazil. Acta Amazonica 30:441-448. https://doi.org/10. 1590/1809-43922000303448

Parolin P, Armbruester N, Wittmann F, Ferreira L, Piedade MTF, Junk WJ (2002) Review of tree phenology in central amazonian floodplains. Pesquisas Botanica 52:195-222

Parolin P, de Simone O, Haase K, Waldhoff D, Rottenberger S, Kuhn U, Kesselmeier J, Kleiss B, Schmidt W, Piedade MTF, Junk WJ (2004) Central Amazonian floodplain forests: tree adaptations in a pulsing system. The Bot Rev 70:357-380. https://doi.org/10.1663/00068101(2004)070[0357:CAFFTA]2.0.CO;2

Pérez-Harguindeguy N, Díaz S, Lavorel S, Poorter H, Jaureguiberry P, Bret-Harte MS, Cornwell WK, Craine JM, Gurvich DE, Urcelay C, Veneklaas EJ, Reich PB, Poorter L, Wright IJ, Ray P, Enrico L, Pausas JG, de Vos AC, Buchmann N, Funes G, Quétier F, Hodgson JG, Thompson K, Morgan HD, ter Steege H, van der Heijden MGA, Sack L, Blonder B, Poschlod P, Vaieretti MV, Conti G, Staver AC, Aquino S, Cornelissen JHC (2013) New Handbook for standardized measurment of plant functional traits worldwide. Aust J Bot 23:167-234. https://doi.org/10.1071/ BT12225

Poorter L, Bongers L, Bongers F (2006) Architecture of 54 moist-forest tree species: traits, trade-offs, and functional groups. Ecology 87:1289-1301. https://doi.org/10.1890/ 0012-9658(2006)87[1289:AOMTST]2.0.CO;2 
Quesada CA, Lloyd J, Anderson LO, Fyllas NM, Schwarz M, Czimczik CI (2011) Soils of Amazonia with particular reference to the RAINFOR sites. Biogeosciences 8:1415-1440. https://doi.org/10.5194/bg-8-1415-2011

$\mathrm{R}$ development Core Team www.R-project.org R: A language and environment for statistical computing.

Reich PB (2014) The world-wide "fast-slow" plant economics spectrum: a traits manifesto. J Ecol 102:275-301. https:// doi.org/10.1111/1365-2745.12211

Reich PB, Wright IJ, Cavender-Bares J, Craine JM, Oleksyn J, Westoby M, Walters MB (2003) The evolution of plant functional variation: traits, spectra, and strategies. Int J Plant Sci 164:S143-S164. https://doi.org/10.1086/374368

Schöngart J, Piedade MTF, Ludwigshausen S, Horna V, Worbes M (2002) Phenology and stem-growth periodicity of tree species in Amazonian floodplain forests. J Trop Ecol 18:581-597. https://doi.org/10.1017/S0266467402002389

Sioli H (1984) The Amazon and its main affluents: hydrography, morphology of the river courses and river types. The Amazon: limnology and landscape ecology of mighty tropical river and its basin, first. Springer, Dordrecht, pp 127-165

Embrapa Solos (1997) Manual de Métodos de Análise de Solo, second. Rio de Janeiro

Embrapa Solos (2000) Métodos de Análise de Tecidos Vegetais Utilizados na Embrapa Solos. Rio de Janeiro

Swenson NG (2013) The assembly of tropical tree communities-the advances and shortcomings of phylogenetic and functional trait analyses. Ecography 36:264-276. https:// doi.org/10.1111/j.1600-0587.2012.00121.x

Swenson NG, Enquist BJ (2008) The relationship between stem and branch wood specific gravity and the ability of each measure to predict leaf area. Am J Bot 95:516-519. https:// doi.org/10.3732/ajb.95.4.516

Swenson NG, Enquist BJ (2009) Opposing assembly mechanisms in a Neotropical dry forest: implications for phylogenetic and functional community ecology. Ecology 90(8):2161-2170

Violle C, Bonis A, Plantegenest M, Cudennec C, Damgaard C, Marion B, le Cœur D, Bouzillé JB (2011) Plant functional traits capture species richness variations along a flooding gradient. Oikos 120:389-398. https://doi.org/10.1111/j. 1600-0706.2010.18525.x

Violle C, Enquist BJ, McGill BJ, Jiang L, Albert CH, Hulshof C, Jung V, Messier J (2012) The return of the variance: intraspecific variability in community ecology. Trends
Ecol Evol 27:244-252. https://doi.org/10.1016/j.tree.2011. 11.014

Westoby M, Wright IJ (2006) Land-plant ecology on the basis of functional traits. Trends Ecol Evol 21:261-268. https://doi. org/10.1016/j.tree.2006.02.004

Wittmann F, Junk WJ (2003) Sapling communities in Amazonian white- water forests. J Biogeogr 30:1533-1544

Wittmann F, Anhuf D, Funk WJ (2002) Tree species distribution and community structure of central Amazonian várzea forests by remote-sensing techniques. J Trop Ecol 18:805-820. https://doi.org/10.1017/S0266467402002523

Wittmann F, Junk WJ, Piedade MTF (2004) The várzea forests in Amazonia: flooding and the highly dynamic geomorphology interact with natural forest succession. For Ecol Manag 196:199-212. https://doi.org/10.1016/j.foreco. 2004.02.060

Wittmann F, Schöngart J, Montero JC, Motzer T, Junk WJ, Piedade MTF, Queiroz HL, Worbes M (2006) Tree species composition and diversity gradients in white-water forests across the Amazon Basin. J Biogeogr 33:1334-1347. https://doi.org/10.1111/j.1365-2699.2006.01495.x

Wittmann F, Schöngart J, de Brito JM, de Wittmann AO, Piedade MTF, Parolin P, Junk WJ, Guillaumet J (2010a) Manual of trees of Central Amazonian várzea floodplains: taxonomy, ecology and use, 1st edn. Editora Inpa, Manaus

Wittmann F, Schöngart J, Junk WJ (2010b) Phytogeography, species diversity, community structure and dynamics of central Amazonian floodplain forests. In: Junk WJ, Piedade MTF, Wittmann F, Schöngart J, Parolin P (eds) Amazonian Floodplain forests: ecophysiology, biodiversity and sustainable management (ecological studies), 1st edn. Elsevier, Dordrecht, pp 62-102

Wright IJ, Reich PB, Westoby M, Ackerly DD, Baruch Z, Bongers F, Cavender-Bares J, Chapin T, Cornelissen JHC, Diemer M, Flexas J, Garnier E, Groom PK, Gulias J, Hikosaka K, Lamont BB, Lee T, Lee W, Lusk C, Midgley JJ, Navas M-L, Niinemets U, Oleksyn J, Osada N, Poorter H, Poot P, Prior L, Pyankov VI, Roumet C, Thomas SC, Tjoelker MG, Veneklaas EJ, Villar R (2004) The worldwide leaf economics spectrum. Nature 428:821-827. https://doi.org/10.1038/nature02403

Publisher's Note Springer Nature remains neutral with regard to jurisdictional claims in published maps and institutional affiliations. 